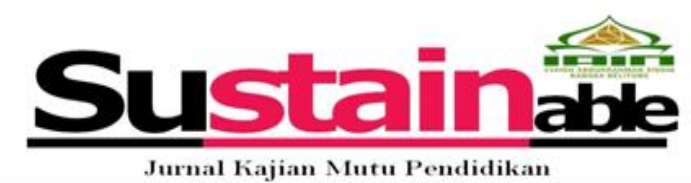

LPM IAIN Syaikh Abdurrahman Siddik Bangka Belitung

https://jurnal.lp2msasbabel.ac.id/index.php/sus, ISSN 2655-0695 (Online)

\title{
Peran Kepala Sekolah Dalam Mengembangkan Kultur Sekolah di SD Negeri 5 Mendo Barat
}

\author{
The Role of The Head of Schools In Developing School Culture In SDN 5 Mendo Barat \\ Muhammad Iqbal Arrosyad ${ }^{1}$, Laela Fitria Ulfa ${ }^{2}$, Cindy Claudia ${ }^{3}$, Indah Eka Safitri ${ }^{4}$, Mersy ${ }^{5}$ \\ ${ }^{12345}$ STKIP Muhammadiyah Bangka Belitung, Indonesia
}

Keywords

the role of principal

school culture

\begin{abstract}
The purpose of this study is to describe: (1) the role of the principal in developing school culture, (2) the supporting and inhibiting factors of the principal in developing school culture. This type of research uses descriptive qualitative methods. The Research subjects are the principal, teachers, and students. For data collection techniques carried out through interviews and documentation with research information consisting of school principals, teachers, and students of SD Negeri 5 Mendo Barat. Data obtained by observation and interviews for ten days. The results of the study are as follows: (1) the role of the principal in developing school culture, namely as leadership, as an innovator, as a motivator and as a manager, (2) supporting and inhibiting factors in the principal in developing school culture, (3) elementary school culture Negeri 5 Mendo Barat is very diverse, in its implementation it takes awareness and habituation every day both in the classroom and outside the classroom, (4) joint efforts of teachers in developing a better school culture, (5) the characteristics of school culture built by principals in public elementary schools 5 Mendo west.
\end{abstract}

\begin{abstract}
Abstrak
Tujuan penelitian ini adalah untuk mendeskripsikan: (1) peran kepala sekolah dalam mengembangkan kultur sekolah, (2) faktor pendukung dan penghambat kepala sekolah dalam mengembangkan kultur sekolah. Jenis penelitian ini menggunakan metode deskriptif kualitatif.Subjek penelitian adalah kepala sekolah, guru, dan siswa.Untuk teknik pengumpulan data dilakukan melalui wawancara dan dokumentasi dengan informasi penelitian terdiri dari kepala sekolah, guru, dan peserta didik SD Negeri 5 Mendo Barat. Data diperoleh dengan cara pengamatan dan wawancara selama sepuluh hari. Hasil penelitian adalah sebagai berikut : (1) peran kepala sekolah dalam mengembangkan kultur sekolah, yaitu sebagai kepemimpinan, sebagai inovator, sebagai motivator dan sebagai manejer, (2) faktor pendukung dan penghambat kepala sekolah dalam mengembangkan kultur sekolah, (3) kultur sekolah SD Negeri 5 Mendo barat sangat beragam, dalam pelaksanaannya dibutuhkan kesadaran dan pembiasaan setiap hari baik didalam kelas maupun diluar kelas, (4) upaya bersama guru dalam mengembangkan kultur sekolah yang lebih baik, (5) karakteristik kultur sekolah yang dibangun oleh kepala sekolah di SD Negeri 5 Mendo barat.
\end{abstract}

\author{
Kata Kunci \\ peran kepala sekolah \\ kultur sekolah
}

Korespondensi

Muhammad Iqbal Arrosyad, muhammad.iqbalarrosyad@stkipmbb.ac.id 


\section{Pendahuluan}

Telah banyak upaya yang dilakukan untuk meningkatkan kualitas sekolah, namun hasilnya belum memuaskan.Salah satu sebabnya yaitu upaya peningkatan kualitas berada diluar sekolah, pendekata sentralistik terbukti tak memberikan jaminan pada akselerasi kualitas sekolah. Oleh karena itu dinamo peningkatan kualitas harus diletakkan kembali ke tempat semestinya, yakni di sekolah(Siswanto, 2013).

Kegiatan pembelajaran dalam kurikulum 2013 diarahkan untuk memberdayakan semua potensi yang dimiliki siswa agar mereka dapat memiliki kompetensi yang diharapkan melalui upaya menumbuhkan serta mengembangkan; sikap/attitude, pengetahuan/knowledge, dan keterampilan/skill (Mulyadin, 2016). Maka dari itu kepala sekolah sangat berperan penting dalam pengembangan kultur sekolah guna untuk mengembangkan sikap, pengetahuan dan keterampilan siswa SD Negeri 5 Mendo Barat.

Sekolah merupakan tempat berlangsungnya kegiatan belajar mengajar. Belajar dan mengajar tidak hanya sebagai kegiatan transfer ilmu dari guru ke siswa. Berbagai kegiatan yang membiasakan seluruh warga sekolah disiplin dan patuh terhadap peraturan yang berlaku di sekolah.Kegiatan di sekolah dapat terlaksana dengan baik berkat adanya peran kepala sekolah. Kepala sekolah yang baik adalah yang mampu mengelola program dan tujuan sekolah yang baik, visi dan misi, serta strategi pendidikan yang utuh dan berpusat kepada mutu, semua dapat terlaksana jika terdapat kerjasama semua warga sekolah (Di et al., 2016).

Teori kepemimpinan bermanfaat bagi setiap pemimpin dalam menjalankan perannya sebagai seorang pemimpin pendidikan. Peran kepala sekolah (Husaini, 2013) sebagai pemimpin pendidikan antara lain: “(1) sebagai personal, (2) educator/pendidik, (3) manager, (4) administrator, (5) supervisor, (6) social, (7) leader, (8) entrepreneur, dan (9) climator/pencipta iklim kerja." Deal dan Kennedy (Depdiknas Direktorat Pendidikan Menengah Umum, 2013:3) mendefinisikan kultur sekolah sebagai keyakinan dan nilai-niali milik bersama yang menjadi pengikat kuat kebersamaan mereka sebagai warga suatu masyarakat. Depdiknas (2004:1) menyatakan bahwa setiap sekolah mempunyai kultur yang harus dipahami dan dilibatkan agar perubahan yang terjadi bisa berlangsung terus menerus tidak sekedar di permukaan. Kultur sekolah akan menjelaskan bagaimana sekolah berfungsi dan mekanisme internal yang terjadi. Para siswa masuk ke sekolah dengan bekal kultur yang dimiliki, sebagian bersifat positif, yaitu yang mendukung peningkatan kualitas pembelajaran.

Kepala sekolah merupakan salah satu komponen pendidikan yang paling berperan dalam meningkatkan kualitas pendidikan. Seperti diungkapkan Supriadi (E. Mulyasa, 2013) bahwa: "Erat hubungannya antara mutu kepala sekolah dengan berbagai aspek kehidupan sekolah seperti disiplin sekolah, iklim budaya sekolah, dan menurunnya perilaku nakal peserta didik". menurut Deal dan Peterson dalam (Zamroni, 2011) menyatakan bahwa kultur sekolah memiliki dorongan atau pendukung, serta memiliki dampak yang kuat dalam meningkatkan prestasi, dan berfungsi dalam mengembangkan bagaimana warga sekolah berpikir, bersikap dan bertindak dalam keseharianya. Dengan mengembangkan kultur sekolah sangat berpengaruh dalam membangun sekolah yang unggul serta mendorong terjadinya peningkatan mutu pendidikan, karena pengaruh mengembangkan kultur sekolah dapat mempengaruhi keadaan lingkungan dan warga sekolah, serta dapat meningkatkan prestasi belajar dan mutu sebuah sekolah.

Pelaksanaan kultur sekolah juga dilaksanakan oleh sekolah lain seperti yang disampaikan (Ilmasari \& Alhadi, 2019)peran kepala sekolah dalam mengembangkan kultur sekolah melalui 4 peran yaitu peran kepala sekolah sebagai manajer,peran kepala sekolah sebagai pemimpin, peran kepala sekolah sebagai inovator dan peran kepala sekolah sebagai motivator. Dan juga (Siswanto, 2013) menyatakan bahwa keadaan kultur sekolah terdiri dari enam aspek budaya, yaitu berprestasi dan berkompetisi, disiplin dan efisien, jujur dan terbuka, gemar membaca, teguran dan penghargaan, serta kerja sama dan kebersamaan, selain itu juga ada keadaan kultur social yang berkembang di sekolah dari aspek budaya, diantaranya jujur, dan terbuka, teguran dan penghargaan, kerjasama dan kebersamaan, daling menghormati, bersih, disiplin, dan efisien. Berdasarkan penelitian lain tersebut bahwa terdapat beberap hal yang bersangkutan terhadap 
penelitian ini terkait kultur yang ada disekolah dengan arahan dari kepala sekolah.

Observasi dan wawancara awal ditemukan bahwa kepemimpinan kepala sekolah di SD Negeri 5 Mendo Barat sudah berjalan cukup baik, kepala sekolah bekerja sama seusuai dengan tugas dan tanggung jawabnya, namun masih terdapat beberapa kekurangan khususnya dalam mewujudkan kultur sekolah, misalnya dalam kedisiplinan, masih ditemukan beberapa peserta didik dan guru yang datang terlambat, belum terlaksananya semua budaya sekolah oleh warga sekolah dengan konsisten, masih ada peserta didik yang belum memakai atribut sekolah(seragam sekolah) dengan lengkap serta konsep pengembangan kultur sekolah yang belum dipahami seutuhnya oleh warga sekolah, khususnya peserta didik. Hal tersebut dikarenakan oleh beberapa faktor, yaitu faktor internal dan eksternal.

Dalam rangka mewujudkan keberhasilan sekolah yang termuat pada visi dan misi serta program sekolah maka kepala sekolah dituntut memiliki kemampuan manajemen dan kepentingan yang tangguh agar mampu mengambil keputusan serta kerjasama dengan seluruh warga sekolah untuk mewujudkan tujuan yang telah ditetapkan. Adapun tujuan yang ingin dicapaidalam penelitian ini adalah untuk mengetahui peran kepala sekolah dalam mengembangkan kultur sekolah, faktor pendukung dan penghambat kepala sekolah dalam mengembangkan kultur sekolah.

\section{Metode}

Jenis penelitian ini menggunakan metode deskriptif kualitatif.Subjek penelitian adalah kepala sekolah, guru, dan siswa.Untuk teknik pengumpulan data dilakukan melalui wawancara dan dokumentasi dengan informasi penelitian terdiri dari kepala sekolah, guru, dan peserta didik SD Negeri 5 Mendo Barat. Data diperoleh dengan cara pengamatan dan wawancara selama sepuluh hari.

Teknik penelitian yang dilakukan lebihlanjut, peneliti menggunakan wawancara semiterstruktur, observasi yang dikunakan dalam penelitian ini merupakan oebservasi non partisipatif, yakni peneliti hanya melakukan pengamatan dan mencatat perilaku-perilaku yang tampak pada onjek penelitian ataupun dari subjek penelitian.Selanjutnya teknik keabsahan data yang digunakan dalam penelitian ini menggunakan teknik triangulasi. Teknik triangulasi sumber yakni menganalisis data secara interaktif model Miles dan Huberman. Sedangkan analisis data pada penelitian ini yaitu hasil data yang terkumpul ditelaah dengan berbagai sumber yang telah didapat dari lapangan, yang telah didapat dengan cara wawancara dan didukung dengan observasi dan pencermatan dokumentasi terkait.

\section{Hasil dan Diskusi}

\section{Peran Kepala Sekolah dalam Mengembangkan Kultur Sekolah}

Dalam rangka mewujudkan keberhasilan sekolah yang termuat pada visi dan misi serta program sekolah maka kepala sekolah dituntut memiliki kemampuan manajemen dan kepentingan yang tangguh agar mampu mengambil keputusan serta kerjasama dengan seluruh warga sekolah untuk mewujudkan tujuan yang telah ditetapkan. Adapun tujuan yang ingin dicapaidalam penelitian ini adalah untuk mengetahui peran kepala sekolah dalam mengembangkan kultur sekolah, faktor pendukung dan penghambat kepala sekolah dalam mengembangkan kultur sekolah.

Observasi dan wawancara awal ditemukan bahwa kepemimpinan kepala sekolah di SD Negeri 5 Mendo Barat sudah berjalan cukup baik, kepala sekolah bekerja sama seusuai dengan tugas dan tanggung jawabnya, namun masih terdapat beberapa kekurangan khususnya dalam mewujudkan kultur sekolah, misalnya dalam kedisiplinan, masih ditemukan beberapa peserta didik dan guru yang datang terlambat, belum terlaksananya semua budaya sekolah oleh warga sekolah dengan konsisten, masih ada peserta didik yang belum memakai atribut sekolah(seragam sekolah) dengan lengkap serta konsep pengembangan kultur sekolah yang belum dipahami seutuhnya oleh warga sekolah, khususnya peserta didik. Hal tersebut dikarenakan oleh beberapa faktor, yaitu faktor internal dan eksternal. 
Peran Kepala Sekolah dalam Mengembangkan Kultur Sekolah Peran kepala sekolah menurut (Fatimaningrum, 2012) terdiri dari 7 peran yaitu peran kepala sekolah sebagai pendidik, manajer, pemimpin, administrator, supervisior, inovator dan motivator namun dalam penelitian ini hanya terdapat 4 peran yang akan dibahas karena mendominasi kepala sekolah dalam mengembangkan kultur sekolah yaitu peran kepala sekolah sebagai manajer, pemimpin, Inovator serta motivator.

\section{Peran Kepala Sekolah sebagai Manajer}

Seorang manajer atau kepala sekolah pada hakikatnya adalah seorang perencana, organisator, pemimpin, dan seorang pengendali. Keberadaan manajer pada suatu organisasi sangat diperlukan, sebab organisasi sebagai alat mencapai tujuan organisasi dimana di dalamnya berkembang berbagai macam pengetahuan, serta organisasi yang menjadi tempat untuk membina dan mengembangkan karier-karier sumber daya manusia, memerlukan manajer yang mampu untuk merencanakan, mengorganisasikan, memimpin, dan mengendalikan agar organisasi dapat mencapai tujuan yang telah ditetapkan (Di et al., 2016).

Peran kepala sekolah sebagai manajer dalam mengembangkan kultur sekolah di SD Negeri 5 Mendo Barat, kepala sekolah mengambil tindakan atau upaya yang diambil berupa melakukan rapat mengenai apa yang perlu dikembangkan dengan bertukar pendapat dengan guru-guru kemudian merancang program yang akan di terapkan, lalu bersama-sama mensosialisasikan serta menerapkanya ke warga sekolah.

\section{Peran Kepala Sekolah Sebagai Kepemimpinan}

Kepemimpinan merupakan proses mempengaruhi orang lain untuk mencapai tujuan organisasi. Dapat diartikan bahwa kepemimpinan terjadi pada saat seseorang menggunakan pengaruhnya kepada orang lain terhadap pencapaian tujuan dalam suatu organisasi (Koesmono, 2003).Peran kepala sekolah sebagai pemimpin dalam mengembangkan kultur sekolah juga terlihat bagaimana sikap maupun cara kepala sekolah mengatasi konflik di sekolah khususnya masalah mengenai kultur sekolah negatif yang ada di sekolah dengan bermusyawarah atau dibicarakan bersama guru untuk menemukan cara penyelesaianya atau solusinya.

Kepala sekolah membiasan komunikasi dengan para guru guna mendapatkan solusi ataupun kesepakatan bersama dalam menyelesaikan masalah ataupun konflik yang ada mengenai kultur sekolah yang ada. dalam mengambil keputusan kepala sekolah dituntut untuk dapat melibatkan seluruh komponen yang ada, dengan mengedepankan sistem permusyawaratan. Walaupun pada akhirnya suatu keputusan ada ditangan kepala sekolah, ia harus membicarakan bersama dengan seluruh dewan guru atau komite sekolah secara bersama.(Ilmasari \& Alhadi, 2019).

Peran kepala sekolah sebagai pemimpin dalam mengembangkan kultur sekolah di SD Negeri 5 Mendo Barat salah satunya yang dilakukan oleh kepala sekolah dengan memberikan arahan kepada guru dalam menerapkan kultur sekolah dengan mengingatkan guru serta meminta guru untuk melakukan pengawasan terhadap penerapan kultur sekolah.

\section{Peran Kepala Sekolah Sebagai Inovator}

Peran kepala sekolah sebagai inovator dalam mengembangkan kultur sekolah adalah bagaimana kepala sekolah dapat menjadi seorang yang kreatif dalam mengembangkan sebuah kultur sekolah dari yang sudah ada sebelumnya dan kemudian memunculkan pembaruan berupa kultur yang lebih baik(Ilmasari \& Alhadi, 2019). Kepala sekolah yang memiliki keterampilan dalam menemukan cara atau trik yang dapat digunakan untuk mengembangkan kultur sekolah. Dengan demikian, kepala sekolah dapat merencanakan, merumuskan ide-ide sehingga sekolah dalam perkembangannya senantiasa menemukan inovasi baru dalam perkembangan kultur sekolahnya.

Peran kepala sekolah di SD Negeri 5 Mendo Barat dalam mengembangkan kultur sekolah yaitu melaksanakan apel pagi bagi seluruh kelas 1-6, yang dulunya tidak ada sama sekali kultur sekolah apel pagi. Serta membuat kegiatan kultum setiap hari Jum'at dimana seluruh peserta didik dikumpulkan dihalaman sekolah untuk melakukan sholawat bersama, membaca asmaul husna, dan mendengarkan ceramah yang dilakukan oleh salah satu siswa. 


\section{Peran Kepala Sekolah Sebagai Motivator}

Sebagai motivator dinyatakan bahwa kepala sekolah sebagai pemimpin puncak disekolah merasa memiliki kewajiban untuk memotivasi semua warga sekolah agar selalu dapat mengimplementasikan nilai-nilai karakter sesuai dengan filsafat pancasila dan nilai-nilai religious (Ningsih et al., 2016). Peran kepala sekolah di sd negeri 5 Mendo Barat sebagai motivator harus memiliki kemampuan memberikan motivasi dan dorongan kepada seluruh warga sekolah. Dengan memberikan dukungan dan penghargaan kepada seluruh warga sekolah khususnya peserta didik guna memberikan motivasi peserta didik yang berprestasi.

\section{Faktor Pendukung dan Penghambat Kepala Sekolah dalam mengembangkan Kultur Sekolah}

Berdasarkan hasil wawancara dengan kepala sekolah yaitu Farlina, S.Pd.I. Faktor pendukung kepala sekolah dalam mengembangkan kultur sekolah di SD Negeri 5 Mendo Barat yaitu dukungan yang diberikan oleh warga sekolah baik guru, staff tata usaha, dan juga wali murid sangat membantu dalam mengembagkan kultur sekolah khususnya penerapan kultur yang dikembangkan oleh sekolah. Hal tersebut sependapat dengan (Daryanto \& Karim, 2017) sebuah komunitas sekolah merupakan sebuah tim atau kumpulan dari individuindividu yang bekerja sama untuk mencapai tujuan.

Adapun penghambat kepala sekolah dalam mengembangkan kultur sekolah terkait peran kepala sekolah dalam mengembangkan kultur sekolah yaitu kepala sekolah sebagai pemimpin belum mampu bersikap tegas terhadap pelangaran-pelangaran yang dilakukan warga sekolah, hanya teguran serta hukuman ringan yang dijalankan kepala sekolah, kepala sekolah sebagai pejabat dalam sekolah belum mampu membagi waktu antara kepentingan pribadi maupun kepentingan sekolah sehingga membuat kepala sekolah sering meningalkan sekolah untuk berkegiatan di luar sekolah. hal ini sependapat dengan (Asmani, 2014) Profesionalitas kepala sekolah menjadi syarat mutlak terwujudnya sekolah yang berdaya saing tinggi.

\section{Upaya Bersama Guru dalam Mengembangkan Kultur Sekolah yang Baik}

Upaya-upaya guru dalam mengembangkan kultur sekolah yang baik, diantaranya guru membantu untuk meningkatkan kinerja siswa pada proses pembelajaran, dan meningkatkan hubungan social dengan siswa dikelas maupun diluar kelas seperti hubungan komunikasi dengan keluarga atau orang tua dirumah, hasil wawancara dengan guru SD Neheri 5 Mendo Barat. Upayaupaya meningkatkan kinerja siswa pada proses pembelajaran dirinya sangatlah penting terutama karena pada hakikatnya merekalah pemilik sekolah. Kultur sekolah berpengaruh pada perilaku peserta didik.Perilaku siswa terbentuk pada dua faktor, pertama karakteristik dan lingkungan siswa, baik lingkungan keluarga maupun lingkungan sosial. Kedua kualitas kehidupan terbentuk oleh hubungan formal maupun non formal (Muthmainnah, 2018).

Tantangan terkait tanggung jawab dalam kerangka penguatan budaya kerja sangat akan tergantung pada upaya sekolah mendorong dan menfasilitasi penginternalisasian nilai-nilai disekolah. Kepala sekolah beserta peserta didiknya harus memiliki semngat kepedulian yang tinggi pada apa yang peserta didik harapkan. Mereka bisa merencang kebijakan tentang bagaimana bergerak, bagaimana sebuah nilai-nilai budaya kerja dikuatkan disekolah (Sutjipto, 2019).

Untuk mengambangkan kultur sekolah yang baik seorang guru harus mengembangkan keterampilan yang terdiri dari kemampuan untuk berkomunikasi dan mendiskusikan isu-isu pendidikan dengan khalayak yang lebih luas. Tujuan dilakukannya upaya seperti ini supaya siswa merasa aman dan nyaman ketika berada di kelas ataupun di sekolah.Siswa menjadi lebih terbuka terhadap guru dan tidak merasa tertekan. Guru dan siswa tidak hanya berinteraksi di dalam kelas namun juga di luar kelas (Diani \& Farida Hanum, 2017).

\section{Karakteristik Kultur Sekolah yang diBangun Kepala Sekolah di SD Negeri 5 Mendo Barat Kegiatan Rutin di Sekolah}

Kegiatan rutin di sekolah terdiri dari salaman pagi didepan gerbang sekolah, apel pagi sebelum masuk kelas, berdoa, literasi selama 15 menit, kegiatan pembelajaran sampai usai yaitu berdoa, dan salaman. di SD Negeri 5 Mendo Barat kegiatannya sangat beragam. Untuk penggunaan seragam 
sekolah telah diatur pada tata tertib sekolah. Untuk seragam putih merah dikenakan pada hari Senin dan Selasa, Rabu dan Kamis mengenakan baju batik, Jum'at mengenakan baju muslim, dan sabtu mengenakan baju olahraga.

\section{Kegiatan Kultur Sekolah Lainnya}

Kebersihan di SD Negeri 5 Mendo Barat Sekolah juga sudah menyediakan tempat sampah di setiap kelas. Anjuran menjaga kebersihan di SD Negeri 5 Mendo Barat dilakukan oleh seluruh siswa, guru, kepala sekolah dan staf tata usaha. Dengan cara membuat jadwal piket kelas untuk setiap kelas dari kelas 1 sampai kelas 6 dengan tujuan membersihkan ruang kelas masing-masing.

Siswa dan guru juga memiliki jadwal piket umum yang bertujauan untuk membersih lingkungan sekolah. Biasanya anjuran menjaga kebersihan juga dilakukan secara langsung oleh guru dengan cara langsung turun kelapangan ketika istirahat untuk mengingatkan siswa untuk membuang sampah ke tempat sampah. Sedangkan suasana lingkungan sekolah di SD Negeri 5 Mendo Barat juga menyenangkan Untuk suasana dilingkungan SD Negeri 5 Mendo Barat sudah menyenangkan, siswa - siswa difasilitasi taman bermain. Ketika istirahat siswa bermain dan membeli makanan yang dijual di kantin sekolah.Lingkungannya pun asri membuat siswa lebih nyaman berada di lingkungan sekolah dan menyenangkan.

Menurut hasil pengamatan kami dilapangan, agar terciptanya suasana tenang didalam kelas yaitu guru memiliki teknik mengelola kelas. Dimana guru mengkontrol langsung kegiatan belajar siswa.Sikap kepemimpinan, penguasaan dan penanganan tingkah laku siswa berperan penting untuk menciptakan suasana tenang didalam kelas.Sedangkan untuk terciptanya suasana nyaman didalam kelas guru melakukan jadwal piket kelas agar kelas bersih dan memberikan kesan nyaman saat berada didalam kelas. Dan juga terdapat pojok baja disetiap kelas, hal ini juga membuat kesan nyaman dan membuat siswa/i jadi semakin nyaman berada didalam kelas.

Indikator budaya sekolah yang baik menurut (Lazwardi, 2017) beberapa diantaranya 1) Posterposter anirmasi (pesan positif) dipajang dan digunakan di berbagai tempat strategis yang mudah dilihat oleh warga sekolah. 2) Lingkungan sekolah ditata sehingga asri, teduh dan nyaman. 3) Tujuan sekolah diperlihatkan dengan jelas kepada seluruh warga sekolah, ditetapkan dan diumumkan. 4) Kondisi kelas menyenangkan sehingga mendorong peserta didik untuk belajar

\section{Kesimpulan}

Berdasarkan hasil penelitian dapat ditarik kesimpulan yaitu, peran kepala sekolah dalam mengembangkan kultur sekolah, yaitu sebagai kepemimpinan, sebagai inovator, sebagai motivator dan sebagai manejer. Faktor pendukung dan penghambat kepala sekolah dalam mengembangkan kultur sekolahyaitu faktor pendukungnya adalah dukungan yang diberikan oleh warga sekolah baik guru, staff tata usaha, dan juga wali murid sangat membantu dalam mengembagkan kultur sekolah khususnya penerapan kultur yang dikembangkan oleh sekolah. Sedangkan faktor penghambatnya yaitu kepala sekolah sebagai pemimpin belum mampu bersikap tegas terhadap pelangaranpelangaran yang dilakukan warga sekolah, hanya teguran serta hukuman ringan yang dijalankan kepala sekolah, kepala sekolah sebagai pejabat dalam sekolah belum mampu membagi waktu antara kepentingan pribadi maupun kepentingan sekolah kultur sekolah SD Negeri 5 Mendo barat sangat beragam, dalam pelaksanaannya dibutuhkan kesadaran dan pembiasaan setiap hari baik didalam kelas maupun diluar kelas. Upaya bersama guru dalam mengembangkan kultur sekolah yang lebih baik, upaya-upaya guru dalam mengembangkan kultur sekolah yang baik, diantaranya guru membantu untuk meningkatkan kinerja siswa pada proses pembelajaran, dan meningkatkan hubungan sosial dengan siswa dikelas maupun diluar kelas seperti hubungan komunikasi dengan keluarga atau orang tua dirumah. Karakteristik kultur sekolah yang dibangun oleh kepala sekolah diantaranya kegiatan rutin di sekolah terdiri dari salaman pagi didepan gerbang sekolah, apel pagi sebelum masuk kelas, berdoa, literasi selama 15 menit, kegiatan pembelajaran sampai usai yaitu berdoa, dan salaman. 


\section{Referensi}

Asmani, J. (2014). 7 Tips Aplikasi PAKEM (Pembelajaran Aktif, Kreatif, Efektif, dan Menyenangkan). Jogjakarta: Diva Press.

Daryanto, \& Karim, S. (2017). Pembelajaran abad 21. Gaya Media.

Di, S., Negeri, S. D., Tasikmadu, P., \& Tahun, K. (2016). Kepemimpinan kepala sekolah dalam mewujudkan kultur sekolah di sd negeri 1 papahan tasikmadu karanganyar tahun 2015/2016 publikasi ilmiah.

Diani, M. N., \& Farida Hanum. (2017). Kultur Sekolah Dalam Mengembangkan Good School (Sekolah Efektif) di SMA Negeri 3 Yogyakarta. Jurnal Pendidikan Sosiologi, 1(1), 1-13.

E. Mulyasa. (2013). uji kompetensi dan penilaian kinerja guru. In uji kompetensi dan penilaian kinerja guru.

Fatimaningrum, A. S. (2012). Manajemen Kurikulum Pendidikan Dasar. DIseminasi Shortcourse Bermutu DIKTI.

Husaini, U. (2013). Manajemen teori, praktik dan riset pendidikan. In PT. Remaja Rosdakarya.

Ilmasari, F., \& Alhadi, S. (2019). PERAN KEPALA SEKOLAH DALAM MENGEMBANGKAN KULTUR SEKOLAH DI SD MUHAMMADIYAH. 2(1), 19-27.

Koesmono, T. (2003). Peranan Kepemimpinan Dan Budaya Organisasi. Ekuitas, 10(49), 335-348.

LAZWARDI, D. (2017). Manajemen Kurikulum Sebagai Pengembangan Tujuan Pendidikan. Kependidikan Islam.

Mulyadin, M. (2016). Jurnal pendidikan edutama. Jurnal Pendidikan Edutama, 3(2), 31-48. http://ejurnal.ikippgribojonegoro.ac.id/index.php/JPE/article/view/35/35

Muthmainnah, S. N. (2018). Gaya Mengajar Guru Pemula Dan Guru Profesional Dalam Pembelajaran Matematika Smp Di Klaten Teaching Styles of Novice Teachers and Professional Teachers of Mathematics in Junior Secondary School in Klaten. Jurnal Pendidikan Dan Kebudayaan, 3 (2), 202-216.

Ningsih, T., Zamroni, Z., \& Zuchdi, D. (2016). Implementasi Pendidikan Karakter Di Smp Negeri 8 Dan Smp Negeri 9 Purwokerto. Jurnal Pembangunan Pendidikan: Fondasi Dan Aplikasi, 3(2), 225-236. https://doi.org/10.21831/jppfa.v3i2.9811

Siswanto, S. (2013). Pengembangan Model Evaluasi Kultur Sma. Jurnal Penelitian Dan Evaluasi Pendidikan, 17(1), 88-107. https://doi.org/10.21831/pep.v17i1.1363

Sutjipto, S. (2019). Perancangan Kurikulum Sekolah Menengah Kejuruan Sebagai Pranata Budaya Kerja. Jurnal Pendidikan Dan Kebudayaan, 4(1), 102. https://doi.org/10.24832/jpnk.v4i1.1219

Zamroni. (2011). Bahasa dan sastra Indonesia sebagai wahana pendidikan karakter. In Pendidikan Karakter dalam Perspektif Teori dan Praktik. 